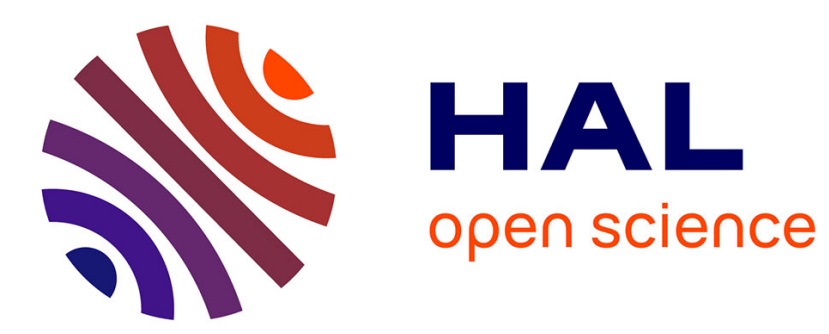

\title{
Performance of impact investing: A value creation approach
}

\author{
Jean-Laurent Viviani, Carole Maurel
}

\section{To cite this version:}

Jean-Laurent Viviani, Carole Maurel. Performance of impact investing: A value creation approach. Research in International Business and Finance, 2019, 47, pp.31-39. 10.1016/j.ribaf.2018.01.001 . halshs-01717992

\section{HAL Id: halshs-01717992 \\ https://shs.hal.science/halshs-01717992}

Submitted on 27 Feb 2018

HAL is a multi-disciplinary open access archive for the deposit and dissemination of scientific research documents, whether they are published or not. The documents may come from teaching and research institutions in France or abroad, or from public or private research centers.
L'archive ouverte pluridisciplinaire HAL, est destinée au dépôt et à la diffusion de documents scientifiques de niveau recherche, publiés ou non, émanant des établissements d'enseignement et de recherche français ou étrangers, des laboratoires publics ou privés. 


\section{Accepted Manuscript}

Title: Performance of Impact Investing: A value creation approach

Authors: Jean-Laurent Viviani, Carole Maurel

PII: $\quad$ S0275-5319(17)30651-7

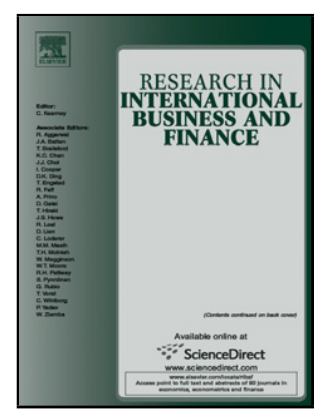

DOI: $\quad$ https://doi.org/10.1016/j.ribaf.2018.01.001

Reference: $\quad$ RIBAF 891

To appear in: $\quad$ Research in International Business and Finance

Received date: $\quad 8-9-2017$

Revised date: $\quad 8-1-2018$

Accepted date: $\quad$ 23-1-2018

Please cite this article as: Viviani, Jean-Laurent, Maurel, Carole, Performance of Impact Investing: A value creation approach.Research in International Business and Finance https://doi.org/10.1016/j.ribaf.2018.01.001

This is a PDF file of an unedited manuscript that has been accepted for publication. As a service to our customers we are providing this early version of the manuscript. The manuscript will undergo copyediting, typesetting, and review of the resulting proof before it is published in its final form. Please note that during the production process errors may be discovered which could affect the content, and all legal disclaimers that apply to the journal pertain. 


\title{
Performance of Impact Investing: A value creation approach
}

\section{Jean-Laurent Viviani}

jean-laurent.viviani@univ-rennes1.fr

IGR-IAE Rennes, CREM

11 rue J. Macé

35708 Rennes

Carole Maurel*

carole.maurel@umontpellier.fr

Université de Montpellier, MRM

Espace Richter, Rue Vendémiaire, Bat B, CS 19519

34960 Montpellier cedex 2

\section{*Corresponding Author}

\begin{abstract}
The purpose of this article is to present an overview about the origins of value creation in impact investing and propose a measure of value creation. According to this point of view, impact investing, i.e. investing in enterprises with a both social and financial objective can be justified only if those enterprises can provide for a higher performance than with a simple portfolio diversification (separate investment in two types of activity). After an overview about the sources of value creation in impact investees as well as about a discussion on existing methods, we propose a method to measure multidimensional value creation.
\end{abstract}

Keywords: impact investee, value creation, social enterprise, impact investing, hybridity.

\section{Introduction}

Research on impact investing has been growing rapidly (see Höchstädter and Scheck, 2015 for an overview), since the birth of the concept ten years ago from the Rockefeller Foundation, along with the impact investment market, which is being more and more structured (Höchstädter and Scheck, 2015). Three categories of stakeholders can be identified; namely impact investors, financial intermediaries and the targets of impact investing. The investees (that we also call multidimensional enterprises) are mainly nonlisted firms financed with debts, private equity or real assets and belonging to the following sectors (in order of importance): housing, energy, microfinance, financial services, food and agriculture and healthcare (GIIN, 2017). One specific feature of impact investees is that they are double and can be even triple bottom-lined, achieving both a social and/or environmental aim alongside a financial return (Millar and Hall, 2013). A growing interest is 
rising around social enterprises, because of the current context of social change and environment protection. Contrary to market-based organizations, social enterprises consider social value creation as central (Thompson 1967; Battilana and Lee, 2014). Nevertheless they also use market-based organizational forms to achieve these objectives. Consequently, they are at the crossroads of the traditional "business" and "charity" model (Battilana and Lee, 2014); for-profit vs. non-for-profit. This double purpose can make them be successful in achieving their social mission, even if some researchers have reservations about the sustainability and effectiveness of such models (Eikenberry 2009; Zahra et al., 2009).

These enterprises need to have formal measures of performance and estimate the outcomes of their activity, at the basis of value creation (Bull, 2007; Ryan and Lyne, 2008). Moreover, even if at the moment most of the investees are non-listed firms, the development of impact investing towards listed ones will require such performance tools. The diversity of supports for these firms (from foundations to private investors) makes it necessary to provide for transparency and accountability (Nicholls, 2009), so that these diversified providers of funds can compare targets and choose to finance the most effective ones (Kroeger and Weber, 2014). The business model of impact investees is often new, what makes it difficult to apply statistical tools and traditional financial analysis (Chell, 2007). They constitute a specific category of non-for-profit organizations, developing innovative ways to tackle complex social problems and fill in the insufficiencies of other non-for-profit organizations. To do so, they take advantage of the combination of social and business logics (Bugg-Levine and Emerson, 2011; Kroeger and Weber, 2014), searching for a blended value (Emerson, 2003 and the "Blended value proposition"). Already in 2002, Lynn Sharpe Pain supported the idea that to be considered as superior performing firms, they had to turn to a shift in value, and consider, besides the financial performance, non-financial one (Sánchez, 2003).

Considering this, value creation in impact investing appears to be a key issue that needs to be clearly framed. Papers studying the different dimensions of value creation in impact investing altogether are scarce. They rather focus on the complex issue of measuring the social impact and social value creation and numerous competing methods exist (Mulgan, 2010). These methods are a sign of the professionalization of the impact investing industry. Social value creation can be defined as "measuring these wider outcomes that can be directly attributed to the actions of an organization after taking into account what would have happened anyway and the contribution of others" (Mulgan, 2010). Existing approaches of social value creation are based on different theoretical frameworks, which are reviewed and discussed by Kroeger and Weber (2014). They develop a framework combining "literature on subjective well-being and the literature on organizational effectiveness theory into not-forprofit and social entrepreneurship". They conclude that existing approaches do not "clearly reflect social value creation" (p. 43) and highlight the need to clarify this notion considering the diversity of situations, enterprises and interventions. Moreover, the existing measures are not used to guide decisions (Mulgan, 2010). On the other hand, we do not intend to discuss the difficulties or virtues of the measure of social impact; the literature is already plethoric on the topic (Nicholls, 2009; Harji and Jackson, 2012). The difficulties met when measuring social impact constitute one of the main obstacles for multidimensional enterprises to raise capital (Antadze and Westley, 2012; Bugg-Levine et al., 2012). 
The purpose of this article is to propose an approach to value creation in impact investing that takes into account both the financial and the non-financial dimension of the investee, i.e. multidimensional enterprises. We want to propose a measure that could guide investment decision, so that the investors could estimate which target is the most appropriate in terms of return and impact (Leat, 2006; Daly, 2011). According to Mulgan (2010), three roles of measures of value creation can be identified: accounting to external stakeholders, managing internal operation and assessing social impact. In this paper, our intention is to focus on the first and the third ones.

The design of a measurement approach depends on the audience and the stakeholders who will use it (Greene, 1994). Some people fear that the use of market-based tools to measure social value is a sign of the "marketization of non-profit organizations" (Arvidson et al., 2013). Proposing an approach of value creation in impact investing implies to take into account both the financial and non-financial dimensions of the activity of the investee. It constitutes a challenge because it means combining financial and non-financial tools without misrepresenting the reality and the heart of the activity of the social enterprise. This is what we will try to do in this paper.

The first section presents the different possible sources and obstacles to value creation in impact investees, the target of impact investing. The second section focuses on the measures of value creation; the existing ones and our approach. The last section concludes, discussing the approach and its limitations.

\section{A specific value creation due to synergies in social enterprises}

In this section, we propose an overview of the possible sources of value creation in impact investing and the existing obstacles or risks related to these sources.

\subsection{Synergies from the hybridity of the impact investee}

In order to understand where value creation comes from in impact investing, we must first be able to distinguish impact investees from other purely social or profit-oriented investees. Indeed, we think that impact investing value creation arises from the singularity of the target of impact investing, i.e. the investee.

\subsubsection{How to identify an impact investee?}

According to Höchstädter and Scheck (2015), impact investing not only targets underserved populations (especially when the impact targeted is environmental). Also, it does not only target developing and emerging countries. Their state of the art shows that the description of the investee is not systematically provided with details in the literature. They should explicitly display a "mission primacy" or be a "social enterprise or social-purpose organizations" and are "unlisted" (p. 458) and can be "for-profit or not-for-profit" (p. 459). Moreover, according to Brown and Swersky (2012), social objectives must be over profit maximizations and profit distribution in favor of the social mission. Besides, in those 
organizations, the role of private, non-listed businesses as impact investees is less clear in the literature.

This lack for clarity and consensus in the characterization of the investee constitutes a weakness for our approach, because we need to distinguish purely social enterprises and purely profit-oriented businesses from what we call "multidimensional enterprises". These enterprises are double (even triple sometimes) bottom lined (Barman, 2015): they pursue a social or environmental mission (or another non-profit-oriented mission) and a profitoriented mission (Emerson and Twersky, 1996). Contrary to classical social organizations, their activity makes money (fees-for-service). The differences go beyond simply adding a financial goal to the social mission. These enterprises are hybrid organizations including parameters belonging to different logics (Pache and Santos, 2013).

Actually, these organizations can be considered as hybrid ones and we think that hybridity of the investee constitutes the heart of value creation in impact investing (Pache and Santos, 2013; Jäger and Schröer, 2013). This feature appears as essential to us (but is not mentioned in Höchstädter and Scheck, 2015).

\subsubsection{Hybridity at the heart of value creation}

This specific profile has several implications, influencing the origins of value creation. Following the traditional approach in finance (Hayek, 1944; Friedman, 1962; HampdenTurner, 1990; Jensen, 2001; Harvey, 2005) multiplicity of goals generates specific and additional costs (inadequate governance structures, inefficient decisions, ineffective incitation systems...) that should lead the multidimensional company to destroy value.

In contrast, we believe that the mix between these two dimensions can lead to innovative and entrepreneurial approaches, likely to create additional value (Wilson and Post, 2013). These enterprises develop specific and new business models, that, when combined to the profit and not-for-profit dimensions, generate social value, which will benefit the different stakeholders (Wilson and Post, 2013). For Wronka (2013) "entrepreneurial, innovative, risk taking behavior" represents a frequent characteristic of successful social enterprises. This is due to the fact that they are able to adapt to the changing environment and to stakeholders' expectations.

Social entrepreneurs have distinctive competencies, ensuring the social and financial viability of their projects. Consequently, social activities are carried out with the same search for efficiency and effectiveness as for commercial activities. This helps them to achieve a social impact as high as purely socially oriented organizations, and clearing at the same time a financial surplus, to attract entrepreneurs and traditional financial backers. Social activities are innovative activities (product, service, process), which help them clear a Schumpeterian rent, or niche activities for which competition is low and return can be high. Doherty et al. (2014) explain that innovative strategies are implemented in social enterprises and help them manage the requests of their stakeholders.

The multidimensional enterprise also creates financial synergies thanks to hybridity. Diversifying activities can create value through coinsurance effect (decrease in default risk 
and consequently in bankruptcy costs, Lewellen, 1971). However, this effect can be counterbalanced by the fact that the enterprise has to choose one sole capital structure to finance activities of different natures and risks (Leland, 2007). In this last case, separating financial and social activities in two distinct units enables each of them to find the most adequate capital structure.

Some investors are ready to accept a lower financial return when compared to the risk they bear. These resources help to reduce the risk of traditional financial resources (Antignac and Attali, 2016). The enterprise can also propose specific return-risk profiles for different types of investors (social investors and classical investors can co-invest in these enterprises). In short, these enterprises can create value by reducing their cost of capital (cost of financial resources) thanks to the greater diversity of investors compared to traditional for-profit organizations.

Creation of financial value by multidimensional enterprises has also to result from innovative financial engineering. The social enterprise needs financial resources to start, grow and reach a critical scale (Harding, 2007; Bloom and Chatterji, 2009). However, conventional finance does not provide for adequate resources to these enterprises (Nicholls, 2010). Consequently, new kinds of financing resources (possibly proposed by new financial institutions) have emerged to finance these categories of enterprises. They are synthesized in Bugg-Levine et al. (2012): loan guarantees, charitable, quasi-equity debts, pooling, social impact bond (SIB), or social impact guarantees (SIG). SIB and SIG are used to avoid over or under-investment in the social mission or the financial goal. It can help avoid the drift towards one dimension rather than the other one. Indeed, return of social bonds increase with the success of the social activities, what should limit the overweighting of the social mission. On the contrary, the return of impact guarantees increases with the financial income or when the social income is weak, what incites the manager to adopt a pro-social behavior.

\subsubsection{Risk induced by hybridity}

The risk with hybridity (and consequently for value creation in impact investees) is the mission drift (Bruneel et al., 2017) or even the mission lock-in, that can lead to a priority to either the financial dimension, or the non-financial one, while we think that value creation comes from the synergy between these two dimensions within one sole enterprise, i.e. the impact investee. Impact investing market fits the paradigm of value plurality (Barman, 2015), defined as the "concurrent co-existence of different valuations" (Helgesson and Muniesa, 2013: 6). As Barman (2015) explains, multidimensional enterprises both create financial value and social and environmental value from their business model. Either should the enterprise trade-off between financial and non-financial objectives or should we consider that the social value is a condition to achieving financial goals (Dacin et al., 2010, 2011; Wilson and Post, 2013). In any case, the risk is to turn into a mission drift in favor of financial sustainability and to the detriment of the social objectives (Cetindamar and Ozkazanc-Pan, 2017). On the scale of the impact investment, this plurality should be considered when measuring the different dimensions of the value created by this specific kind of investment, because the plurality of objectives constitutes one of the explanations of value plurality. The origin of value can neither be only the financial dimension, nor only the social one, but the 
combination of both. In consequence, contrary to shareholder value creation (measured through financial return and risk), social value creation should be measured according to three dimensions: financial return, social impact and risk.

\subsection{Synergies from reciprocity between the investee and other impact stakeholders}

Besides value creation from the hybridity of the investee itself, we think that value creation in impact investing can be enhanced by the reciprocity and cooperation of the different stakeholders engaged in impact investing, reducing existing agency problems.

\subsubsection{Agency conflicts related to the financing of impact investees}

Financing impact investee is likely to lead to important agency conflicts. Agency problems can be observed between managers and investors, and also among different categories of investors. Regarding the first category of conflict, the double purpose of the enterprise and the fact that the social impact is often difficult to measure, make an attractive way to extract the managerial rent (Masulis and Reza, 2015). The second conflict opposes investors preferring the social mission to those preferring financial profitability. However, Chowdhry et al. (2013) propose a model in which, thanks to innovative financial instruments such as impact bonds and guarantees, interests of these two stakeholders can be aligned. Moreover, reciprocity can help to reduce and even avoid sometimes these problems.

In their study, Achleitner et al. (2014) explain that social enterprises rather display a concentrated financing structure because of the agency conflicts they face when diversifying their financing resources. Actually, these conflicts can come from the differences in return requirement, but also from the design of financial instruments used to finance these enterprises. They also explain that social enterprises have to adapt to the expectations to the providers of funds in order to be granted some funds. Obtaining financing capital constitutes a key issue for those enterprises, determining their ability to be launched and developed (Clarkin and Congioni, 2016).

\subsubsection{Reciprocity to reduce agency conflicts}

Consequently, a fit between the interests of different stakeholders is necessary to reduce or even solve these conflicts. Indeed, confidence between collaborators and shared common values are a strong leverage to fight against moral hazard and opportunistic behaviors related to the financing relationship (Cornée and Szafarz, 2014). As shown in Akerlof and Kranton's model (2000), belonging to a social identity plays a key role in solving the principal-agent conflict. Moral hazard is reduced because the agent (here the enterprise) identifies with values of the principal (the investor). Moreover, identity-sharing reinforces reciprocity between agents (Chen and Li, 2009; McLeish and Oxoby, 2011), reducing agency costs and creating value through the development of relational capital. Wilson and Post (2013) explain that the interconnectedness between stakeholders is at the basis of the business model of the impact investee and it drives value creation.

According to Cornée and Szafarz (2014), if the bank shares the identity of the multidimensional entrepreneur, it will propose lower interest rates and expects no strategic 
default (principle of reciprocity). Their conclusions are obvious when identity is not shared: the bank will fund inefficient projects. On the contrary, when identity is shared, funded projects are efficient. Their empirical study confirms these hypotheses, showing first that there actually exists a reciprocity mechanism from borrowers (decrease in the probability of default). Second, banks propose below-market interest rates to social borrowers, leading to a decrease in cost of capital.

To solve agency conflicts, the management of intermediaries engaged in impact investing relies on such fundamental principles as transparency and responsibility (Cowton and Thompson, 2000; Cowton, 2002; Bechetti et al., 2011; San-José et al., 2011).

\section{How to measure value creation in impact investing}

The previous section introduced the sources of value creation in impact financing, i.e. the hybridity of the investees as well as the reciprocity between the different stakeholders engaged in impact investing aimed at reducing agency costs. Therefore, this first section insists on the plurality of value in impact investing. We will now review and discuss existing value creation proposition before presenting our approach, relying on the principles presented in section 1.

Traditional measures of social impact are constructed to answer the question: is it better to invest on social activity A or social activity B? From our point of view, these measures fail to take into account the hybridity of multidimensional organizations. For these specific organizations, the relevant question is rather: should I invest in a multidimensional company or in an equivalent portfolio of for-profit and non-for profit organizations? To give a parallel in the financial literature one question is: should I invest in the pharmaceutical or in the entertainment industry? Another one is: should I invest in a firm diversified in the pharmaceutical and entertainment industry or in a portfolio of companies that are pure players of each industry? We hence would like to know whether the investor should obtain better results (financial and non-financial) by investing in a multidimensional company (the impact investee) or if this investor should split his investment among two different targets, one with a purely financial objective and the other with a purely social and/or environmental objective. That is the difference between the results of the two strategies that we call (by analogy with financial value creation) the value creation of the multidimensional company. The measure of social value creation raises two questions: a first about the measure and comparability of social impacts; this question regards all kinds of organizations, multidimensional or not: we give a brief overview of this this problem below. The second question, which we are dealing with in this article, concerns specifically the measure of value creation of multidimensional enterprises.

\subsection{Value creation in II: overview of the literature}

Now, let's propose an overview of the key challenge induced by impact investing in terms of value creation measure (the plurality of value), completed by a review and a discussion of existing measures.

\subsubsection{Combining financial and non-financial considerations}


The specific feature of impact investing when compared to other types of investments relies in the fact that to the classical return-risk approach of value and performance, one must also consider a third dimension, i.e. the impact. Actually, value creation measure must incorporate the multidimensionality of the investee and the combined effect of these specific features. The difficulty with social enterprises is that they blur the boundaries between the private and non-profit sectors (Dees, 1998).

\subsubsection{Overview of existing measures}

Traditionally, financial value creation echoes with the return and risk approach and with the portfolio theory developed by Markowitz (1952). An investor will generally expect a certain level of return in relation with the level of risk which is supported. However, when searching for "value creation" in "impact investing", we noticed that the literature on impact investing focuses on the measurement of the social impact. The social value, composing value creation in impact investing is "subjective, malleable and variable" (Watson and Whitley, 2016). Mulgan (2010) proposed an overview about the measure of social value. He explains the difference between output and outcome ${ }^{1}$, when dealing with social value, and highlights the difficulty to quantify and measure it. According to Mulgan (2010), even if there is no official definition of social value, it can refer to "wider non-financial impacts of programmes, organizations and interventions, including the wellbeing of individuals and communities, social capital and the environment." They identify four methods: cost benefit analysis, social accounting, basic efficiency resource analysis and social return on investment (SROI) ${ }^{2}$; the last one being one of the most used methods because it has the advantage to combine the Social Impact Assessment (SIA) practices and cost-benefit analysis.

The main challenge of the measure of social value is to ensure comparability between different activities or entities (Kroeger and Weber, 2014). To solve this problem, Social Return On Investment (SROI) methodology estimates the monetary equivalent of social value created and compare this equivalent to input used (also monetized). To overcome the monetization problem Kroeger and Weber (2014) propose to compare the subjective wellbeing (subjective satisfaction) generated by different social programs. Nevertheless, if this approach theoretically solves the problem, practically, it seems to be quite difficult to implement.

The interest of the approach we propose comes from the fact that, unlike the SROI (Manetti, 2012), we do not need to monetize the non-financial impact ${ }^{3}$. However, our approach implies to find social organizations and for-profit companies with similar activities than the multidimensional organization. Moreover, it goes beyond a purely subjective measure of value creation, summarized by the slogan "I am the market ", in which each investor compares the financial and social incomes to his/her own subjective benchmark. If the

\footnotetext{
1 Output: activities done by an organization; outcome: long term observed effects of the outputs (Mulgan, 2010). They can be considered as the social value.

${ }^{2}$ For recent development of SROI the reader can refer to the special issue of Evaluation and Program Planning (Volume 64, Pages 1-144, October 2017) entirely dedicated to SROI.

${ }^{3}$ The monetization process faces obstacles that are summarized by Lingane and Olsen (2004).
} 
subjective approach can be justified from an individual investor's point of view; it becomes more difficult to implement for a fund manager who is accountable to many investors, each having his/her own subjective benchmarks.

\subsection{Measure of value creation for the multidimensional company}

This approach is based on what was explained in section 1 about the multidimensionality of impact investees and the search for both a financial and a non-financial return for investors. As explained above, value creation is grounded on the comparison between the results obtained by the entity studied and the results obtained from the best possible alternative. Therefore, in the case of the multidimensional enterprise value creation must be based on two comparisons one with comparable (same risk, size, activity...) for-profit organizations (for the financial dimension) and one with non-for profit organization (for the non-financial dimension). 
The method is synthetized in the following graph ${ }^{4}$.

\begin{tabular}{|c|c|c|}
\hline $\begin{array}{l}\text { Sample of } \\
\text { comparable (similar } \\
\text { activities and/or } \\
\text { risk) for-profit } \\
\text { organizations } \\
\Rightarrow \text { Equivalent } \mathrm{FI} / \mathrm{Cl}\end{array}$ & $\begin{array}{l}\text { Multidimensional } \\
\text { organization } \\
\text { (to be evaluated) }\end{array}$ & $\begin{array}{c}\text { Sample of comparable } \\
\text { (similar impact, } \\
\text { supposed to be } \\
\text { measurable) non-for- } \\
\text { profit organizations } \\
\Rightarrow \text { Equivalent } \mathrm{NFI} / \mathrm{Cl}\end{array}$ \\
\hline
\end{tabular}

FI: financial impact; NFI: non-financial impact; Cl: capital invested.

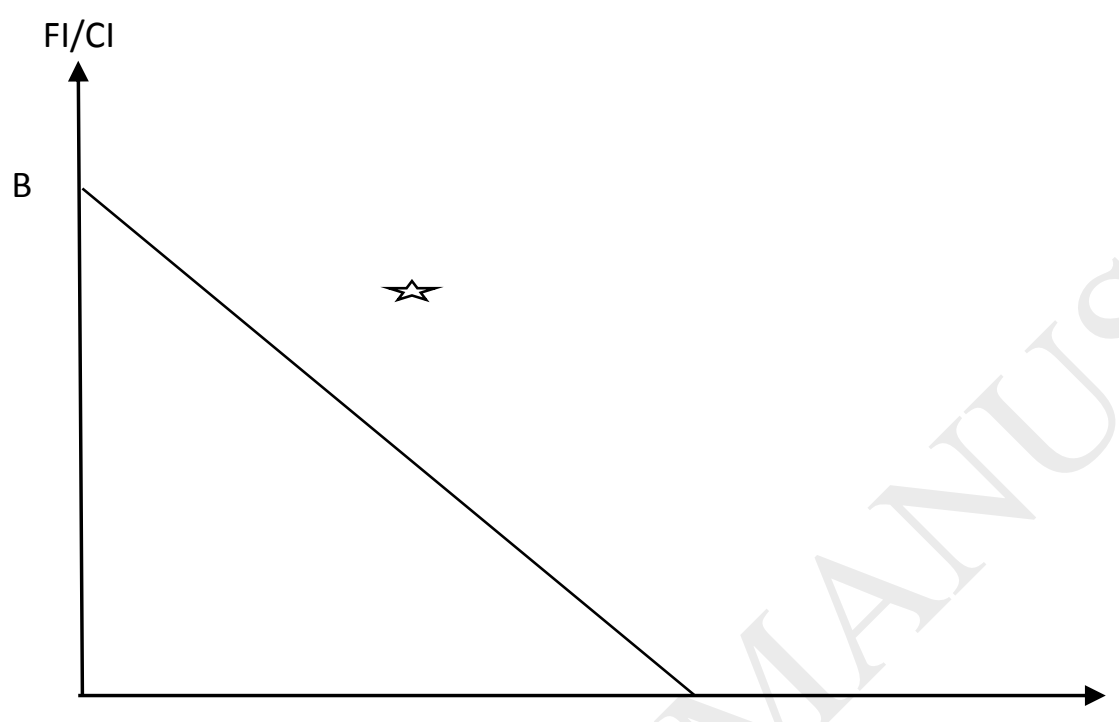

A

$\mathrm{NFI} / \mathrm{Cl}$

Graph 1. Measuring Social Value Creation of multidimensional enterprises

If one invests $100 \%$ of his/her wealth ( $\mathrm{Cl}$ : capital invested) in equivalent non-for-profit organizations, it will obtain a $\mathrm{NFI} / \mathrm{Cl}$ ratio given by $\mathrm{A}$. If one invests $100 \%$ of his/her wealth in equivalent for-profit organizations it will obtain a $\mathrm{FI} / \mathrm{Cl}$ ratio of $\mathrm{B}$. The straight line $[\mathrm{A}, \mathrm{B}]$ gives the combination of $\mathrm{NFI} / \mathrm{Cl}, \mathrm{Fl} / \mathrm{Cl}$ that can be obtained by a mere portfolio combination of forprofit and non-for-profit organizations. A multidimensional organization creates (destroys) value if it is above (below) this straight line.

We propose an approach to transform a two-dimension problem (financial performance and non-financial impact) into a unique performance measure by "projecting" value creation either on the financial dimension, or on the social one.

\subsubsection{Projection on the social dimension}

\footnotetext{
${ }^{4}$ Our method can be seen as an operationalization of the "social business thinking " model presented in Wilson and Post (2013).
} 
An investor want to compare the outcome (financial and non-financial) obtained by investing an amount $\mathrm{Cl}$ (capital invested) in a multidimensional enterprise, with the outcome it would have obtained by investing the same amount in a portfolio of enterprises maximizing financial value (called private-sector organizations by Doherty et al., 2014) and of not-forprofit organizations with a similar mission.

First, financial performance of the social enterprise is compared to that of private sectors organizations. The financial outcome obtained from the social enterprise is: $R_{F I N} \equiv C I \times r$, with $r$ : return on equity of the multidimensional organization.

We are then looking for how much one should invest in an equivalent for-profit organization, so that the financial outcome of the multidimensional enterprise $\left(R_{F I N}\right)$ is equal to financial outcome of the equivalent company $\left(R_{F I N}^{E}\right)$.The amount to invest in the equivalent profit maximizing company $\left(\mathrm{Cl}_{\mathrm{E}}\right)$ is solution of the following equation (1):

$$
R_{F I N} \equiv C I \times r=C I_{E} \times r_{E} \equiv R_{F I N}^{E}
$$

with $r_{E}$ : expected return on equity of an equivalent for-profit organization.

Eq. (1) says that to invest $C I$ in the multidimensional company leads to the same financial outcome than to invest $C I_{E}$ in an equivalent purely for-profit organization.

The equivalent for-profit organization should theoretically be a company with the same systematic risk than the multidimensional organization. In this case, the expected return of the private sector organization is given by a model, for instance the Capital Asset Pricing Model (CAPM). In this case, we have $r_{E}=R_{F}+\beta\left[E\left(R_{M}\right)-R_{F}\right]$.

$\beta$ : systematic risk of the multidimensional enterprise,

$R_{F}, E\left(R_{M}\right)$ : risk free rate and expected return of the market portfolio respectively.

In case of SMEs systematic risk can be very difficult to compute but it is possible to use the well-known and accepted comparable method. The expected return $\left(r_{E}\right)$ is the mean return of a sample of profit-maximizing companies similar (same industry, similar size and activities) to the multidimensional organization.

The second step helps to compare the non-financial performance of the multidimensional organization with that of non-for-profit organizations with similar social goals.

If, $r_{E}>r$ from Eq. (1), $C I_{E}<C I$, hence the amount one can devote to the social activities is equal to: $C I-C I_{E}=C I\left(1-\frac{r}{r_{E}}\right)$. The social value creation (SVC) is given by the gap between the non-financial impact of the social enterprise (NFI) and the non-financial impact of an equivalent non-for-profit organization. We suppose that the NFI of the multidimensional organization can be measured, but by difference with SROI, it is not necessary to monetize it. To find the equivalent $N F I\left(N F I_{E}\right)$, the first step is to define a sample of similar non-forprofit organizations and the second step is to compute the impact obtained by a given amount invested. The generic formula is: 
The function $f$ in Eq. (2) can be seen as the production function of the equivalent non-forprofit organization. As in the traditional comparable method, we can suppose that the function $f$ is linear, it is given by the ratio $a=N F I / C I$ (note that if $N F I$ and $C I$ are expressed in monetary terms, this ratio a is the SROI) and equation (2) becomes $N F I_{E}=a\left(C I-C I_{E}\right)$.

Finally, the social value creation is given by:

$$
S V C=N F I-N F I_{E}
$$

As already explained value creation is the difference between what is obtained thanks to the multidimensional organization and what is obtained by the best alternative.

Example: Let us estimate the social value creation of a social enterprise (SE1) with equity equal to 100 monetary units. Its return on equity is equal to $5 \%$ for a social output of 10,000 (we voluntary do not put any unit because the social output can be measured in monetary units but also in quantity of goods distributed, in number of people receiving a service, in degree of satisfaction...).

Return on equity for an equivalent profit-maximizing company is $10 \%$. So, the equivalent capital employed is: $C I_{E}=100 \frac{5 \%}{10 \%}=50$. The investor can obtain the same financial income that the one obtained by investing in the multidimensional enterprise by investing only 50 in a private sector organization. So, the other part of the investment amount to be devoted to social activities is 50 . Considering that one invested unit (in an equivalenrt purely social organization) generates on average 180 of social output.

Creation of social value is: $\mathrm{SVC}=10,000-180 \times 50=1,000$. It means that investing in the multidimensional enterprise generated a higher social value $(1,000)$ than with an equivalent investment in a portfolio composed of a for-profit organization and a non-for-profit social organization. The social value creation ratio equals: $\mathrm{SVC} / \mathrm{Cl}=10$.

By the way, the lower is financial performance of the multidimensional organization, the higher its social performance should be. In effect, by combining equations (2) and (3) we obtain:

$$
\begin{aligned}
& S V C=N F I-a \times C I\left(1-\frac{r}{r_{E}}\right) \\
& S V C=N F I+\frac{a \times C I}{r_{E}} r-a \times C I
\end{aligned}
$$

Last expression in Eq. (4) clearly shows that social value creation is a linear and positive function of the performance in both dimensions social $(N F I)$ and financial $(r)$ and negative one of the characteristics of the best alternative ( $a$ and $r_{E}$ ). 
In the previous example, if return on equity of a multidimensional enterprise (SE2) is equal to $2.5 \%$, so equivalent capital employed is 25 ; it is possible to invest 75 in social activities, which lead to 13,500 of output. Investment in private enterprises with a similar risk and in not-for-profit social activities helps generate an additional social output of 3,500 when compared to the investment in the multidimensional enterprise. Put another way, destruction of social value is equal to 3,500 in this case. If in the multidimensional enterprise, return on equity is equal to the expected return, then, social value creation equals the social impact. By using equation (4) we obtain:

$$
S V C=10000-180 \times 100\left(1-\frac{2,5 \%}{10 \%}\right)=-3500
$$

We can also find the minimum financial return the multidimensional company should reach in order to obtain a positive SVC.

$$
0=N F I-a C I\left(1-\frac{r}{r_{E}}\right) \Leftrightarrow\left(1-\frac{N F I}{a C I}\right) r_{E}=r_{M I N}
$$

With data given in the example we find: $r_{M I N}=4.44 \%$.

Taking into account its non-financial impact, the multidimensional company should obtain at the minimum a financial profitability of $4.44 \%$.

Finally, a problem arises if the return on equity of the multidimensional enterprise is higher than the expected return. In this case, financial value creation is traditionally measured with the residual financial income: $C I \times\left(r-r_{E}\right)$ and social value creation is equal to the social impact of the enterprise.

\subsubsection{Projection on the financial dimension}

To equal the non-financial impact of a multidimensional enterprise, Capital Invested in notfor-profit organizations needs to be equal to: $C I_{N}=f^{-1}(N F I)$.

Financial income produced by the amount which can be invested in financial activities is: $r_{E}\left(C I-C I_{E}\right)$.

Social value creation is given by the following equation: $S V C=R_{F I N}-r_{E}\left(C I-C I_{E}\right)$.

In the previous example, the requested capital employed is equal to: $C I_{N}=\frac{10000}{180}=55.56$.

The equivalent financial income is: $10 \%(100-55.56)=4.44$.

Consequently, social value creation is: $S V C=5-4.44=0.56$. That means that the multidimensional enterprise reaches the same social outcome than the portfolio strategy but allows achieving a higher financial income.

Graph 2 is the specific case of graph 1 to represent the social value creation of SE1. The vertical (horizontal) double arrows segment is the projection of SVC on the axis of financial (non-financial) performance. 


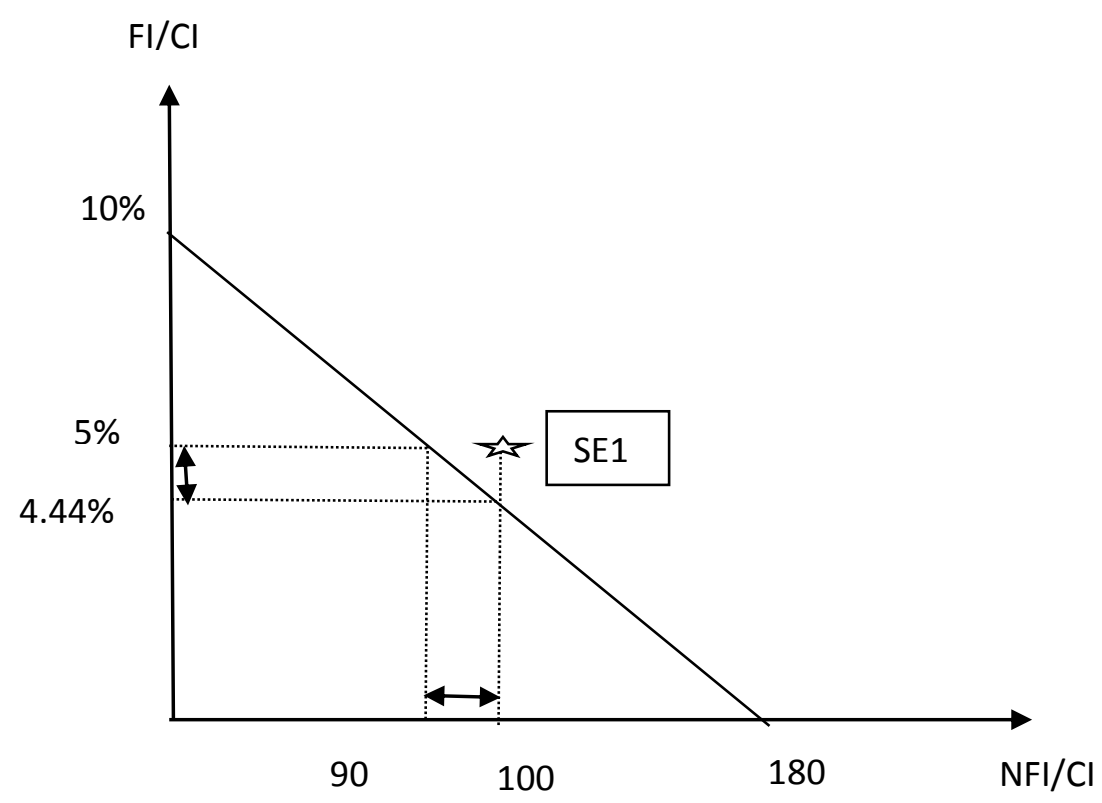

Graph 2: Measuring Social Value Creation of multidimensional enterprises (an illustration)

\subsubsection{Elasticity of substitution}

In our example, if we separate the dimensions, giving up one unit of financial income allow to make available ten units of equity, which will be invested in purely social activities, clearing an impact of 1,800 . Ten units of equity in the multidimensional enterprise yield both 0.5 financial units and an impact of 1,000, i.e. an elasticity of substitution of 2,000. Therefore, it is more efficient to invest in a multidimensional enterprise. More generally speaking, we have to compare the elasticity of substitution between financial and nonfinancial income: $e_{N F I, R_{F I N}}=\left(\frac{d N F I / d C I}{d R_{F I N} / d C I}\right)$ when financial and non-financial activities are combined or not.

\section{Conclusion}

The purpose of this article was to discuss and justify the existence of impact investing, by proposing an enlarged view of value creation. According to this point of view, impact investing, summarized as investment in enterprises with a double (and even triple) purpose, both social and financial, can be justified only if these enterprises can do better than just a portfolio diversification (separate investments in two types of activities).

To tackle this issue, we first propose a literature review on the origins of value creation in impact investing. Actually, value creation comes from synergies generated by the hybridity of social enterprises targeted by impact investors. This value creation is possible only if the social enterprise does not turn to a mission drift or mission lock in. Value creation also comes from the reciprocity necessary between the different stakeholders engaged in impact investing. This reciprocity helps reduce agency problems and enhance performance.

The value is based on the target of the investment, i.e. the multidimensional enterprise or impact investee. Beside some classical resources and capabilities, these investees have to be 
endowed with specific features to be more attractive than separate investments in the investor's portfolio (i.e. an investment in a profit-oriented organization and another one in a not-for-profit oriented organization). Indeed, their hybridity, innovativeness, as well as the financial synergies can constitute key assets for these enterprises, even if they also have to face a series of obstacles, among which mission drift and lock-in are the main ones.

We also propose a method to measure multidimensional value creation. The aim of this method is to transform this multidimensional value into a unique performance measure, by projecting value creation either on the financial dimension or on the social one.

This contribution has inevitably some limitations. Among them, the implementation of such an approach depends on our ability to distinguish multidimensional enterprises (impact investees) from purely social organizations as well as purely market-oriented ones. Maybe the use of case study will help us. Moreover, one can question the use of the CAPM to estimate the expected return on equity, as we are supposed to deal with non-listed firms. This can be improved. Another limitation is related to the non-financial impact itself and its measure. In this approach we consider it as given, but we know that there still remain a lot of works to develop about it. Last, there is still a lot to do to apply this approach to existing enterprises, in order to know to what extent our model is operational or must be adapted.

This article aimed at proposing a framework adapted to the specific case of value creation in impact investing. The next step consists in adding an empirical view to this measure in order to see to what extent it can fit with the reality of multidimensional stakeholders. It could provide for a key tool for enterprises as well as for institutions and investors, who will be able to compare value creation among different investment opportunities. Moreover, if our arguments match with the reality of these enterprises, it will help develop impact investing and consequently incite investors to adopt a more responsible behavior, without excluding financial performance.

\section{References}

Achleitner, A. K., Spiess-Knafl, W., Volk, S. 2014. The financing structure of social enterprises: conflicts and implications. International Journal of Entrepreneurial Venturing, 6(1), 85-99.

Akerlof, G. A., Kranton, R. E. 2000. Economics and identity. Quarterly Journal of Economics, $115,715-733$.

Antadze, N., Westley, F. R. 2012. Impact Metrics for Social Innovation: Barriers or Bridges to Radical Change? Journal of Social Entrepreneurship, 3(2), 133-150.

Antignac, C., Attali, B. 2016. L'investissement à haut rendement sociétal, Les essentiels de la banque et de la finance, RB Edition.

Arvidson, M., Lyon, F., McKay, S., Moro, D. 2013. Valuing the social? The nature and controversies of measuring social return on investment (SROI). Voluntary Sector Review, 4(1), 3-18.

Battilana, J., Lee, M. 2014. Advancing research on hybrid organizing-Insights from the study of social enterprises. Academy of Management Annals, 8(1), 397-441.

Barman, E. 2015. Of principle and principal: Value plurality in the market of impact investing. Valuation Studies, 3(1), 9-44. 
Becchetti, L., Garcia, M., Trovato, G. 2011. Credit rationing and credit view: Empirical evidence from loan data. Journal of Money, Credit and Banking, 43, 1217-1245.

Bloom, P., Chatterji, A., 2009. Scaling social entrepreneurial impact. California Management Review, 51 (3), 114-133.

Brown, A., Swersky, A. 2012. The First Billion. A forecast of social investment demand. The Boston Consulting Group, Big Society Capital, London.

Bruneel, J., Staessens, M., Cherchye, L., Kerstens, P. J. 2017. Benefit of the Doubt Performance Measurement of Social Enterprises: Mission Lock-in or drift? In Academy of Management Proceedings (Vol. 2017, No. 1, p. 13803). Academy of Management.

Bugg-Levine, A., Emerson, J. 2011. Impact investing: Transforming how we make money while making a difference. Innovations, 6(3), 9-18.

Bugg-Levine, A., Kogut, B., Kulatilaka, N. 2012. A New Approach To Funding Social Enterprises - Unbundling societal benefits and financial returns can dramatically increase investment. Harvard Business Review, 90(1/2), 118-123.

Bull, M. 2007. Balance: The Development of a Social Enterprise Business Performance Tool. Social Enterprise Journal, 3(1): 49-66.

Cetindamar, D., Ozkazanc-Pan, B. 2017. Assessing mission drift at venture capital impact investors. Business Ethics: A European Review. 26(3), 257-270;

Chell, E. 2007. Social Enterprise and Entrepreneurship towards a Convergent Theory of the Entrepreneurial Process. International Small Business Journal 25(1), 5-26.

Chen, Y., Li, S. X. 2009. Group identity and social preferences. American Economic Review, 99, 431-457.

Chowdhry, B. Davies, S.W., Waters, B. 2015. Incentivizing Impact Investing. Working paper, UCLA Anderson School of Management.

Clarkin, J. E., Cangioni, C. 2016. Impact investing: A primer and review of the literature. Entrepreneurship Research Journal, 6(2), 135-173.

Cornée, S., Szafarz, A. 2014. Vive la différence: Social banks and reciprocity in the credit market. Journal of Business Ethics, 125(3), 361-380.

Cowton, C. J. 2002. Integrity, responsibility and affinity: Three aspects of ethics in banking. Business Ethics: A European Review, 11, 393-400.

Cowton, C., Thomspon, P. 2000. Do codes make a difference? The case of bank lending and the environment. Journal of Business Ethics, 24, 165-178.

Dacin, P. A., Dacin, M. T., Matear, M. 2010. Social entrepreneurship: Why we don't need a new theory and how we move forward from here. The academy of management perspectives, 24(3), 37-57.

Dacin, M. T., Dacin, P. A., Tracey, P. 2011. Social entrepreneurship: A critique and future directions. Organization science, 22(5), 1203-1213.

Daly, S. 2011. Philanthropy, the Big Society and emerging philanthropic relationships in the UK. Public Management Review, 13(8), 1077-1094.

Dees, J.G. 1998. Enterprising Nonprofits, Harvard Business Review, Jan-Feb. 55-67.

Doherty, B., Haugh, H., Lyon, F. 2014. Social enterprises as hybrid organizations: A review and research agenda. International Journal of Management Reviews, 16(4), 417-436.

Eikenberry, A. M. 2009. Refusing the market: A democratic discourse for voluntary and nonprofit organizations. Nonprofit and Voluntary Sector Quarterly, 38(4), 582-596.

Emerson, J., Twersky, F. eds. 1996. New Social Entrepreneurs: The Success, Challenge, and Lessons of Non-profit Enterprise Creation. San Francisco: Roberts Foundation. 
Emerson J. 2003. The blended value proposition: integrating social and financial returns. California Management Review, 45(4), 35-51.

Freidman, M. 1962. Capitalism as Freedom, Chicago.

Global Impact Investing Network 2017. Annual Impact Investor Survey.

Greene, J. C. 1994. Qualitative program evaluation. Handbook of qualitative research, 530, 544.

Hampden-Turner, C. 1990. Charting the corporate mind: from dilemma to strategy. Oxford: Blackwell.

Harding, R., 2007. Social entrepreneurship monitor. London: London Business School and Barclays Bank.

Harji, K., Jackson, E. T. 2012. Accelerating Impact - Achievements, Challenges and What's Next in Building the Impact Investing Industry.

Harvey, D. 2005. A Brief History of Neo-Liberalism, Oxford.

Hayek, F. 1944. The Road to Serfdom, Routledge.

Helgesson, C. F., Muniesa, F. 2013. For what it's worth: An introduction to valuation studies. Valuation Studies, 1(1), 1-10.

Höchstädter, A.K., Scheck, B. 2015. What's in a Name: An Analysis of Impact Investing Understandings by Academics and Practitioners, Journal of Business Ethics, 132(2), 449-475.

Jäger, U. P., Schröer, A. 2013. Integrated Organizational Identity: A Definition of Hybrid Organizations and a Research Agenda. VOLUNTAS: International Journal of Voluntary and Nonprofit Organizations, 1-26.

Jensen, M. 2001. Value Maximization, Stakeholder Theory, and the Corporate Objective Function. European Financial Management, 7(3), 297-317.

Kroeger, A., Weber, C. 2014. Developing a conceptual framework for comparing social value creation. Academy of Management Review, 39(4), 513-540.

Kuttner, R. 1997. Everything for Sale: The Virtues and Limits of Markets. New York: Random House.

Leat, D. 2006. Grantmaking foundations and performance measurement: playing pool?. Public Policy and Administration, 21(3), 25-37.

Leland, H.E. 2007. Financial Synergies and the optimal Scope of the firms: implications for mergers, spinoffs, and structured finance. The Journal of Finance, 62(2), 765-807.

Lewellen, W. 1971. A pure financial rationale for conglomerate merger. Journal of Finance, 26, 521-537.

Lingane, A., Olsen, S. 2004. Guidelines for social return on investment. California Management Review, 46(3), 116-135.

McLeish, K. J., Oxoby, R. J. 2011. Social interactions and the salience of social identity. Journal of Economic Psychology, 32, 172-178.

Manetti, G. 2012. The Role of Blended Value Accounting in the Evaluation of Socio-Economic Impact of Social Enterprises. VOLUNTAS: International Journal of Voluntary and Nonprofit Organizations, 25(2), 443-464.

Markowitz, H. 1952. Portfolio selection. The journal of finance, 7(1), 77-91.

Masulis, R., Reza, S. 2015. Agency Problems of Corporate Philanthropy, Review of Financial Studies 28(2), 592-636.

Millar, R., Hall, K. 2013. Social return on investment (SROI) and performance measurement: The opportunities and barriers for social enterprises in health and social care. Public Management Review, 15(6), 923-941. 
Mulgan, G. 2010. Measuring social value. Stanford Soc Innov Rev, 8(3), 38-43.

Nicholls, A. 2009. We do good things, don't we?': 'Blended Value Accounting. Social Entrepreneurship. Accounting, Organizations and Society, 34(6-7), 755-769.

Nicholls, A. 2010. The institutionalization of Social investment: the interplay of investment logics and investor rationalities. Journal of Social entrepreneurship, 1(1), 70-100.

Pache A.C., Santos F. 2013. Inside the hybrid Organization: selective coupling as a response to competing institutional logics. Academy of Management Journal, 56(4), 972-1001.

Ryan, P. W., Lyne, I. 2008. Social Enterprise and the Measurement of Social Value: Methodological Issues with the Calculation and Application of the Social Return on Investment. Education, Knowledge and Economy, 2(3): 223-37.

Sánchez, C. 2003. Reviewed Work: Value Shift: Why Companies Must Merge Social and Financial Imperatives to Achieve Superior Performance by Lynn Sharp Paine The Academy of Management Executive (1993-2005), Vol. 17(2), 142-144.

San-Jose, L., Retolaza, J. L., Gutierrez, J. 2011. Are ethical banks different? A comparative analysis using the radical affinity index. Journal of Business Ethics, 100, 151-173.

Thompson, J. D. 1967. Organizations in action: Social science bases of administrative theory. Transaction publishers.

Watson, K. J., Whitley, T. 2017. Applying social return on investment (SROI) to the built environment. Building Research \& Information, 45(8), 875-891.

Wilson, F., Post, J. E. 2013. Business models for people, planet ( $\&$ profits): exploring the phenomena of social business, a market-based approach to social value creation. Small Business Economics, 40(3), 715-737.

Wronka, M. 2013. Analyzing the success of social enterprises-critical success factors perspective. In Active citizenship by knowledge management $\&$ innovation. Proceedings of the management, knowledge and learning international conference. MakeLearn, Cejle.

Zahra, S., Gedajlovic, E., Neubaum, D., Schulman, J. 2009. A typology of social entrepreneurs: Motives, search processes and ethical challenges. Journal of Business Venturing, 24: 519532. 